$11-25-2018$

\title{
The Paradox of Post-Postmodernism
}

\author{
Seungho Moon \\ Loyola University Chicago, smoon3@luc.edu
}

Follow this and additional works at: https://ecommons.luc.edu/education_facpubs

Part of the Education Commons

\section{Author Manuscript}

This is a pre-publication author manuscript of the final, published article.

\section{Recommended Citation}

Moon, Seungho. The Paradox of Post-Postmodernism. Educational Theory and Philosophy, 50, 14:

1450-1451, 2018. Retrieved from Loyola eCommons, Education: School of Education Faculty Publications and Other Works, http://dx.doi.org/10.1080/00131857.2018.1462450

This Article is brought to you for free and open access by the Faculty Publications and Other Works by Department at Loyola eCommons. It has been accepted for inclusion in Education: School of Education Faculty Publications and Other Works by an authorized administrator of Loyola eCommons. For more information, please contact ecommons@luc.edu. c) $($ ())

This work is licensed under a Creative Commons Attribution-Noncommercial-No Derivative Works 3.0 License. (C) Taylor and Francis, 2018. 


\title{
The paradox of post-postmodernism
}

\author{
Seungho Moon
}

\section{Teaching and learning Program, loyola university chicago, illinois, il, usa}

Post-postmodernism is a paradox. The zeitgeist of twenty- rst century ecologically resides not in a void or a predictable space. Rather, the 'is-ness' of being exists in a paradox paradox refers to the irrational, mystical, contradictory juxtapositions of being in the cosmos. A paradox is engendered discursively while moving beyond a stable, dichotomous format of being as Western Enlightenment movements imply. A paradox of being debunks any binary of body-mind, self-other, or consciousunconscious. Such denial of existential dichotomy pries open a space where a paradox resides with imagination. I argue that a paradox of being and/non-being shifts discourse in educational theory in the era of post-postmodernism. Tao Te Ching [道德經] illustrates the paradoxes of living and existence. Linguistic, metaphoric name of Tao is not Tao anymore [道可道, 非常道]. Tao exists as Tao; yet Tao does not exists as Tao (Jung, 2001). Tao itself is uid in that it shifts being, embodiment, and operations. This paradox of being/non-being and action/non-action of Tao is implemented in the non-action philosophy of wuwei [無爲]: 'No action is undertaken, and yet nothing is left undone' (Chan, 1963, p. 162). A paradox of postpostmodernism embraces not-knowingness of knowing and knowingness of notknowing. This epistemological blind spot of knowing/un-knowing becomes an open-ended space to imagine multiple approaches to interpreting who/what educational theorists are.

By living in this paradox, educational theorists revisit a label of subjectivity or action circulating in institutions. This paradox of Taoist being encourages educators to revisit a normalized usage of 'social justice' in theorizing a just society and education. In Taoist tradition, people do not fully experience social justice if social justice is linguistically determined and institutionalized. Paradoxically, the goal of taking a socially just action aims to remove the term of 'social justice' all together from our lexicon. This provocative idea challenges the reproduction of bifurcated notions of self-other, oppressed-oppressor, and subjectivity-alterity in social justice education. Donghak [Eastern Learning] - Korea's nineteenth century indigenous religion - is an example of applying this paradox of being driven from the blurred boundaries of self-other. The ontological complexity of self-other is generated from Su-un's (the founder) spiritual experience of god's message, 'my heart-mind is no other than your heartmind' (吾心㴧汝 心). This apophatic approach to God from within and without oneself explicates a non-dualistic rela- tionship of self-other (Lee, 2014). This 
blurred, interwoven approach to self-other in the cosmic world challenges bifurcated approaches to self-other or subjectivity-alterity regardless if one follows critical theory or poststructuralist traditions (Wang, 2013). Self-other is interwoven interdependently with the paradox of being that thus cannot be labeled within an anthropocentric approach to human as part of cosmos or $q i$ (Lee, 2014). Educators live in a paradoxical space of Tao and wuwei: Tao is not Tao once it is labeled. Postpostmodernism resides in this unknown space-space where multiple, unknown angles exist in creating $u s$-ness (which is never a uniformed, exclusive format of it). Indeed, a paradox is and is not post-postmodern. 